\title{
STUDENTS SATISFACTION IN MAJOR PUBLIC UNIVERSITY: A PRE-PANDEMIC STUDY IN BANGLADESH
}

\author{
Md. Ali Imran \\ Lecturer \\ Department of Business Administration \\ CCN University of Science \& Technology, Bangladesh \\ Ikbal Ahmed \\ Lecturer \\ Department of CSE \\ CCN University of Science \& Technology, Bangladesh \\ Md. Mazharul Islam Bhuiyan \\ Lecturer \\ Department of Business Administration \\ CCN University of Science \& Technology, Bangladesh

\begin{abstract}
Abu Obida Rahid
Lecturer

Department of Business Administration

CCN University of Science \& Technology, Bangladesh

\section{Noorjahan Begum}

Lecturer

Department of Business Administration

CCN University of Science \& Technology, Bangladesh
\end{abstract}

Received: August 08, 2021 Accepted: August 29, 2021 Online Published: September 26, 2021

DOI: 10.46281/aijssr.v9i1.1355

URL: https://doi.org/10.46281/aijssr.v9i1.1355

\begin{abstract}
Student satisfaction is entitled to the standard facilities enjoyed by the students according to the cherished and standardised criteria. In Bangladesh, public universities are furnishing education to a myriad of students. But in terms of catering privileged prerequisites compare to top-class universities over the globe, we are far behind. To investigate the level of student gratification, we constructed some benchmark questions and collected feedback from five top-rated university students. We focused on various conglomerate issues faced by public university students, aiming to scrutinise the substantive outline. Advance statistical tools are used to analyse the data. We
\end{abstract}


revealed some malaise from the student response. Quite a few strategies and reciprocity from the jurisdiction can quench the environment, which will augment the student satisfaction level.

Keywords: Students Satisfaction, Public University, Bangladesh, Standard Facilities.

\section{INTRODUCTION}

As the proportion of educated workers increases, a country's economy becomes more efficient, as educated workers may perform tasks that require literacy and critical thinking more effectively. Higher education institutions are heavily affected by market globalization. Increased competition has been created to attract students, educational services and improve competition in the international market, thus isolating themselves from their competitors. Many students have been compelled to follow. HEIs also recognised that the industry is in a market meeting or exceeding the needs of its students and concentrating on the representation of the service industry (Gruber et al., 2010). Therefore, much study has been undertaken to define the important things that influence the happiness of students.

Bangladesh is a developing country in which the education sector, an important higher education system, will play a key role in raising the population's standard of living and improving the economy. To this end, the Bangladesh government has taken numerous steps over the past few decades to improve its infrastructure for higher education. A 20-year comprehensive plan (20062026) for the higher education sector has been drawn up by the Government of Bangladesh, taking into account the United Nations Sustainable Development Goals (SDGs), the 2010 National Education Strategy and the 2021 Vision. Consequently, at the same time, undergraduate enrollment in these universities has sharply increased. As a continuation of its objective, the government is trying to create a public university in every district of the country. The government is trying to boost overall industries in Bangladesh by developing more and higher educational institutions. 46 public universities are currently operational in the region, with 284,322 students enrolled at those universities. Besides, the Bangladesh government and other players in higher education have stressed the happiness of students. Public colleges provide their students with numerous facilities for quality education. However, in evaluating students' satisfaction with the facilities offered by public universities in Bangladesh, there is a study discrepancy. Therefore, this analysis aims to analyse the level of student satisfaction with the services offered by public universities in the region. The research also seeks to define the key service variables influencing students' satisfaction at public universities in Bangladesh.

\section{OBJECTIVES}

This study is conducted to ascertain the student's satisfaction in major public universities in Bangladesh. To the epilogue, the main objectives of the study are-

- To examine and analyse the student satisfaction level in major public universities in Bangladesh.

- To focus the measurements of student satisfaction practices in public universities.

- To propose the test of features in terms of students' satisfaction.

- To determine the handicaps in student satisfaction in our major public universities.

- To proffer some suggestion to enhance the facilities to draw student satisfaction. 


\section{LITERATURE REVIEW}

The researchers found that increased quality of service results in greater customer loyalty, which then leads to attracting new consumers and maintaining existing ones. It is possible to accept students as clients of educational institutions. The essential duty of higher education institutions is to provide students with all facets of their facilities and services, so the loyalty of students will be accomplished by developing the perceived standard of service. Marilyn (2005) reported that delivering perceived service quality to their students is the primary priority for higher educational institutions. Providing students with enhanced educational facilities will contribute to the desire for increased revenue for the institutions highly. Services can be described as actions, performances, and processes that one entity or person provides or co-produce for and with another entity or person (Zeithaml et al., 2010). Both core service and physical goods are included in turn according to this definition. The unique characteristics of the education sector make it fall under the category of service (Nadiri et al., 2009).

Any student of higher education institutions expects their institution to have better quality facilities (Douglas, 2011). It is a challenging and crucial concept to provide quality educational facilities in higher education, and it is impossible to guarantee quality services in higher education (Rodney \& John, 2009; Harvey \& Green, 2012). Monitoring and evaluation, technical assistance, benchmarking, and the sharing of best practices may all help to create an Education Management Information System (EMIS) that reflects the school's performance over time. As a consequence, increasing EMIS implementation across the board may lead to higher-quality education and performance in the long run (Helal et al., 2021). The effectiveness of an institution of higher education relies on the standard of the education and education services offered by the institution (Clewes, 2011; Islam \& Salma, 2016). There is no single opinion, however, of the level of operation of higher educational institutions. In other words, various public education organisations and partners have different opinions on high-quality higher education facilities. Universities around the world offer, in addition to tuition, various forms of facilities to ensure quality education (such as housing, travel, athletics, the internet, medical quality, etc.). As a motivational factor, educational facilities offered by university work play an important role in the life of a student (Henning, Langer, \& Hansen, 2001). In these situations, many variables, such as faculty/teaching personnel, counselling staff, and classroom teaching practices, have a significant and constructive effect on the satisfaction of students. The study also stated that these crucial issues should be concentrated on by a higher education institution to increase its students' happiness and motivation. Traditional learning techniques have evolved into a more contemporary form as a result of technological advances that were previously unimaginable. Online teaching and learning is one such revolution in which educational institutions use Information Technology (IT) to guarantee access to materials, improve instructional quality, and decrease the cost of conventional courses (Ahmed et al., 2020).

Government support for higher education and research is not adequate at all, and, where possible, the UGC does not supply public universities with funds (Mobassern \& Muhammed, 2010). There is a long-term relationship between sustainable growth and higher education (Chaudhary, Iqbal, \& Gillani, 2009). Theoretically, various education commissions in Bangladesh have emphasised the unlocking of talent at all levels of society and creating a pool of highly educated people who can contribute to nation-building. However, in reality, the academic level of Bangladeshi universities is inferior, and they have not been able to make any positive progress. During East Pakistan, education policy stressed a human being's legal, ethical and religious growth. 
Nevertheless, after Bangladesh's liberation, the 2010 National Education Policy stressed acquiring advanced expertise and skills. Training leads to every nation's economic growth. Enhancing higher education facilities will draw international students to our country as well as local outgoing students who can raise more government revenue. The standard of education that private universities offer is extremely divisive.

\section{STUDENT SATISFACTION MODEL}

In the satisfactory student model, we discussed three major elements: exceeding expectations and building loyalty, satisfaction, developing confidence, and preventing complaints. These are the levels. If the authority endeavours these types of activities, they can satisfy the students. In our public universities, most of the students agonising some common problems. These can be satisfied through the humble willingness of the concerning authorities.

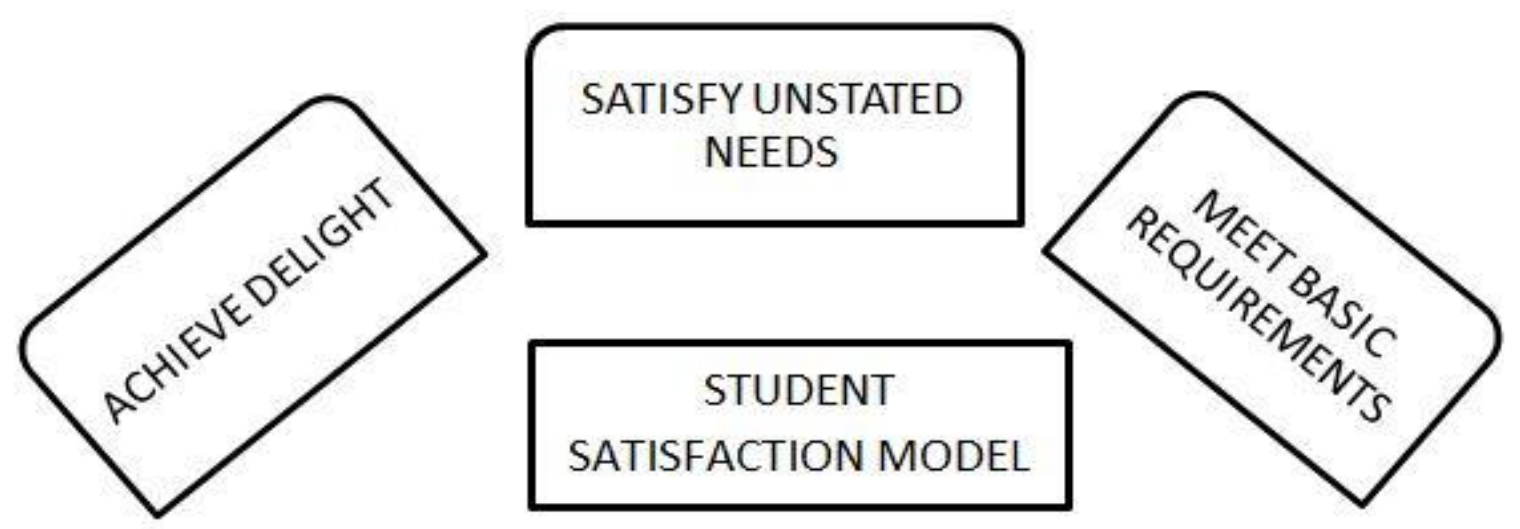

Figure 1. Student Satisfaction Model

Students are the building blocks of a nation. If we can satisfy unstated needs, achieve delights and meet basic requirements in every sector of their academic, learning, research, and practical aspects, they will provide us with an advanced nation. Excellent and satisfactory facilities can change the overall higher education concept in our country. In public universities, students face accommodation problems. The classroom environment is not quite good in some cases. There are not well-structured lab facilities, library and research convenience. Some other university faces transportation problems and so on. If the satisfaction level is secured, we can expect tremendous feedback from our students.

\section{RESEARCH METHODOLOGY \& DATA COLLECTION STRATEGY}

In this research, a cross-sectional survey was conducted in five major universities in Bangladesh. For that reason, an open-ended questionnaire has been set in five points Likert scale to get a more accurate and reliable opinion from the respondents to evaluate the satisfaction level. The scale are below "Extremely satisfied=5, Satisfied=4, Neutral=3, Dissatisfied=2, extremely dissatisfied=1". There are 46 public universities in Bangladesh. We select five major universities to collect our primary data. Primary \& Secondary data are analysed to complete this research. Student satisfaction is the dependent variable here. Independent variables are used to develop the hypothesis and transforming the variable data. Cronbach's Alpha value is used for the reliability test, Kolmogorov-Smirnov and Shapiro-Wilk model is used for the normality test. Multiple regression analysis and correlation coefficient value are used for data analysis. 
Table 1. Independent Variables and Their Measurement

\begin{tabular}{|c|c|c|}
\hline $\begin{array}{l}\text { Independent } \\
\text { variables }\end{array}$ & Measurement & Notation \\
\hline $\begin{array}{l}\text { Institutional } \\
\text { objectives \& } \\
\text { procedures }\end{array}$ & $\begin{array}{l}\text { The institution's vision, mission \& priorities are explicitly stated. } \\
\text { With justice \& openness, scholarly decisions are made. } \\
\text { The expected result of learning (ILOs) follows the stated mission \& goals. } \\
\text { The organisation has ample infrastructure to accommodate its missions. } \\
\text { The university observes the academic calendar. } \\
\text { The results are published timely. } \\
\text { The universities are looking forward to their policy for further betterment. } \\
\text { Code of conducts for both employee and students are maintained properly. } \\
\text { Disciplinary rules are clearly stated by the authority. } \\
\text { University websites are updated timely. } \\
\text { Various methods are followed for achieving learning objectives. }\end{array}$ & OP. \\
\hline $\begin{array}{l}\text { Academic } \\
\text { learning } \\
\text { quality }\end{array}$ & $\begin{array}{l}\text { The university authority ensures a favourable learning environment. } \\
\text { Students' opinion for curricular \& extra-curricular activities has cared. } \\
\text { Teaching strategies are exposed properly in the curriculum. } \\
\text { The assessment process is mentioned in the curriculum clearly. } \\
\text { Curriculum loads are bearable. } \\
\text { The admission procedures are fair to enrol quality students. } \\
\text { Student progress is monitored regularly. } \\
\text { Teachers share the student progress feedback with their students. } \\
\text { Classroom facilities are favourable for learning. } \\
\text { Laboratory facilities are well-established. } \\
\text { The library is updated with its materials to meet the student needs. }\end{array}$ & LQ. \\
\hline $\begin{array}{l}\text { Organisational } \\
\text { and students } \\
\text { development } \\
\text { facilities }\end{array}$ & $\begin{array}{l}\text { Both indoor \& outdoor are adequate. } \\
\text { There are commendable sports facilities (indoor and outdoor). } \\
\text { Gymnasium facilities are sufficient. } \\
\text { Internet facilities are appreciatable. } \\
\text { Interactive learning is practised using modern devices. } \\
\text { Class size is good enough for the learning activities. } \\
\text { The university authority provides practical knowledge to apply in a real-life } \\
\text { situation. } \\
\text { Financial grants are available for poor students. } \\
\text { The university provides extra-curricular facilities to the students. } \\
\text { There is a well-structured and supportive alumni association. } \\
\text { The university possesses good research facilities. } \\
\text { The mechanism encourages students to research activities. }\end{array}$ & SD. \\
\hline $\begin{array}{l}\text { Assessment } \\
\text { methods \& } \\
\text { student } \\
\text { feedback }\end{array}$ & $\begin{array}{l}\text { Evaluation processes are correctly shared with the pupils. } \\
\text { Assessment systems achieve the course's aims. } \\
\text { It follows both formative (quizzes, tasks, term papers, continuous evaluations, } \\
\text { interviews, etc.) and summative evaluation (final examination) methods. } \\
\text { Immediately after the test, the students are given input. } \\
\text { The agency has an obligation to offer learning advice and counselling. } \\
\text { I'm pleased with this university. }\end{array}$ & AF. \\
\hline
\end{tabular}




\section{DATA ANALYSIS}

The respondent's survey result is coded in the SPSS software to analyse the data. Numerous analytical tools are used to conduct this research. Reliability analysis is performed to test the data. Cronbach's alpha value is used for this test.

Table 2. Reliability Statistics

\begin{tabular}{|c|c|}
\hline Cronbach's Alpha value & Number of items observed \\
\hline 0.844 & 47 \\
\hline
\end{tabular}

Cronbach's Alpha greater than or equal to 0.70 means the data are reliable. Here the Cronbach's alpha value is 0.844 , so; we can say that the data are standard. We test the normality of the variables using the Kolmogorov-Smirnov and Shapiro-Wilk model of normality statistics. In both the model the p-value is greater than 0.05 apart from Organisational and student development facilities. We can say all the data are not statistically significant, so the null hypothesis is accepted \& the data are normally distributed. But the Organisational and student development facilities data are not normally distributed.

Table 3. Tests of Normality

\begin{tabular}{|l|r|r|r|r|r|r|}
\hline \multirow{2}{*}{ Variable Title } & \multicolumn{3}{|c|}{ Kolmogorov-Smirnov $^{\mathrm{a}}$} & \multicolumn{3}{c|}{ Shapiro-Wilk } \\
\cline { 2 - 7 } & Statistic & \multicolumn{1}{c|}{ df } & \multicolumn{1}{c|}{ Sig. } & Statistic & \multicolumn{1}{c|}{ df } & \multicolumn{1}{c|}{ Sig. } \\
\hline $\begin{array}{l}\text { Institutional objectives } \\
\text { \& procedures }\end{array}$ & .077 & 87 & $.200^{*}$ & .991 & 87 & .788 \\
\hline $\begin{array}{l}\text { Academic learning } \\
\text { quality }\end{array}$ & .079 & 87 & $.200^{*}$ & .978 & 87 & .138 \\
\hline $\begin{array}{l}\text { Organizational and } \\
\text { students development } \\
\text { facilities }\end{array}$ & .147 & 87 & .000 & .956 & 87 & .005 \\
\hline $\begin{array}{l}\text { Assessment methods \& } \\
\text { student feedback }\end{array}$ & .103 & 87 & .024 & .982 & & \\
\hline
\end{tabular}

\section{$H_{1}:$ Institutional objectives and procedures are maintained properly to procure students' satisfaction.}

From the table 3 for institutional objectives \& procedures the significance (p-value) is 0.356 ; this value is higher than to $\boldsymbol{\alpha}$ level 0.05 for this test. An equal variances $t$-test failed to reveal a statistically reliable difference between the mean number of female $(\mathrm{M}=3.39, \mathrm{SD}=.60)$ and male $(\mathrm{M}=3.18, \mathrm{~s}=.51), t(85)=-1.61, p=.109, \alpha=.05$.If $\mathbf{p} \leq \boldsymbol{\alpha}$, then reject Ho.In Institutional objectives \& procedures, $\mathrm{p}=(0.109)$ is greater than 0.05 , so we accepted $\mathbf{H}_{0}$ and reject $\boldsymbol{H}_{1}$. So we can say, Institutional objectives and procedures are not maintained properly to procure students' satisfaction. 
Table 4. Independent Samples Test

\begin{tabular}{|c|c|c|c|c|c|c|c|c|c|c|}
\hline & \multicolumn{2}{|c|}{$\begin{array}{c}\text { Levene's } \\
\text { Test for } \\
\text { Equality of } \\
\text { Variances }\end{array}$} & \multicolumn{7}{|c|}{ t-test for Equality of Means } \\
\hline & & \multirow[t]{2}{*}{$\mathrm{F}$} & \multirow[t]{2}{*}{ Sig. } & \multirow[t]{2}{*}{$\mathrm{t}$} & \multirow[t]{2}{*}{$\mathrm{df}$} & \multirow[t]{2}{*}{ 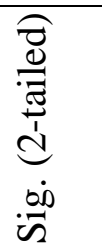 } & \multirow[t]{2}{*}{ 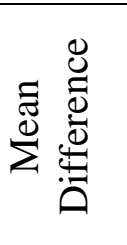 } & \multirow[t]{2}{*}{ 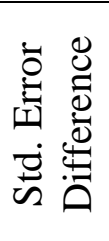 } & \multicolumn{2}{|c|}{$\begin{array}{c}95 \% \\
\text { Confidence } \\
\text { Interval of the } \\
\text { Difference }\end{array}$} \\
\hline & & & & & & & & & Lower & Upper \\
\hline \multirow[t]{2}{*}{$\begin{array}{l}\text { Institutional } \\
\text { objectives \& } \\
\text { procedures }\end{array}$} & $\begin{array}{l}\text { Equal } \\
\text { variances } \\
\text { assumed }\end{array}$ & .861 & .356 & $\begin{array}{r}- \\
1.61 \\
8\end{array}$ & 85 & .109 & $\begin{array}{r}- \\
.20509\end{array}$ & $\begin{array}{r}.126 \\
78\end{array}$ & $\begin{array}{r}- \\
.4571 \\
5 \\
\end{array}$ & $\begin{array}{r}.0469 \\
8\end{array}$ \\
\hline & $\begin{array}{l}\text { Equal } \\
\text { variances not } \\
\text { assumed } \\
\end{array}$ & & & $\begin{array}{r}- \\
1.50 \\
0\end{array}$ & $\begin{array}{r}36.22 \\
6\end{array}$ & .142 & $\begin{array}{r}- \\
.20509\end{array}$ & $\begin{array}{r}.136 \\
76\end{array}$ & $\begin{array}{r}- \\
.4823 \\
8 \\
\end{array}$ & $\begin{array}{r}.0722 \\
1\end{array}$ \\
\hline \multirow[t]{2}{*}{$\begin{array}{l}\text { Academic } \\
\text { learning } \\
\text { quality }\end{array}$} & $\begin{array}{l}\text { Equal } \\
\text { variances } \\
\text { assumed } \\
\end{array}$ & $\begin{array}{r}1.49 \\
6\end{array}$ & .225 & $\begin{array}{r}- \\
1.30 \\
2\end{array}$ & 85 & .196 & $\begin{array}{r}- \\
.15360\end{array}$ & $\begin{array}{r}.117 \\
93\end{array}$ & $\begin{array}{r}- \\
.3880 \\
9 \\
\end{array}$ & $\begin{array}{r}.0808 \\
8\end{array}$ \\
\hline & $\begin{array}{l}\text { Equal } \\
\text { variances not } \\
\text { assumed }\end{array}$ & & & $\begin{array}{r}- \\
1.18 \\
5\end{array}$ & $\begin{array}{r}35.13 \\
2\end{array}$ & .244 & $\begin{array}{r}- \\
.15360\end{array}$ & $\begin{array}{r}.129 \\
60\end{array}$ & $\begin{array}{r}- \\
.4166 \\
8 \\
\end{array}$ & $\begin{array}{r}.1094 \\
7\end{array}$ \\
\hline \multirow{2}{*}{$\begin{array}{l}\text { Organizational } \\
\text { and students } \\
\text { development } \\
\text { facilities }\end{array}$} & $\begin{array}{l}\text { Equal } \\
\text { variances } \\
\text { assumed } \\
\end{array}$ & .301 & .585 & -.950 & 85 & .345 & $\begin{array}{r}- \\
.13905\end{array}$ & $\begin{array}{r}.146 \\
44\end{array}$ & $\begin{array}{r}- \\
.4302 \\
1 \\
\end{array}$ & $\begin{array}{r}1521 \\
0\end{array}$ \\
\hline & $\begin{array}{l}\text { Equal } \\
\text { variances not } \\
\text { assumed } \\
\end{array}$ & & & -.922 & $\begin{array}{r}39.34 \\
3\end{array}$ & .362 & $\begin{array}{r}- \\
.13905\end{array}$ & $\begin{array}{r}.150 \\
79\end{array}$ & $\begin{array}{r}- \\
.4439 \\
6 \\
\end{array}$ & $\begin{array}{r}.1658 \\
5\end{array}$ \\
\hline \multirow{2}{*}{$\begin{array}{l}\text { Assessment } \\
\text { methods \& } \\
\text { student } \\
\text { feedback }\end{array}$} & $\begin{array}{l}\text { Equal } \\
\text { variances } \\
\text { assumed } \\
\end{array}$ & .039 & .844 & -.835 & 85 & .406 & $\begin{array}{r}. \\
.11872\end{array}$ & $\begin{array}{r}.142 \\
24\end{array}$ & $\begin{array}{r}- \\
.4015 \\
2\end{array}$ & $\begin{array}{r}.1640 \\
9\end{array}$ \\
\hline & $\begin{array}{l}\text { Equal } \\
\text { variances not } \\
\text { assumed }\end{array}$ & & & -.823 & $\begin{array}{r}40.53 \\
5\end{array}$ & .415 & $\begin{array}{r}.11872 \\
\end{array}$ & $\begin{array}{r}.144 \\
17\end{array}$ & $\begin{array}{r}- \\
.4099 \\
8\end{array}$ & $\begin{array}{r}.1725 \\
5\end{array}$ \\
\hline
\end{tabular}

\section{$\mathrm{H}_{2}$ : Academic learning qualities are gratifying to persuade students' satisfaction.}

From the table 4 for academic learning qualities the significance (p-value) is 0.225 ; this value is higher than to $\boldsymbol{\alpha}$ level 0.05 for this test. An equal variances $t$-test failed to reveal a statistically reliable difference between the mean number of female $(\mathrm{M}=3.27, \mathrm{SD}=.57)$ and male $(\mathrm{M}=3.12, \mathrm{SD}=.46), t(85)=-1.30, p=.196, \alpha=.05$.If $\mathbf{p} \leq \boldsymbol{\alpha}$, then reject Ho. In Academic learning quality, $\mathrm{p}=(0.196)$ is greater than 0.05 , so we accepted $\mathbf{H}_{\mathbf{0}}$ and reject $\boldsymbol{H}_{\mathbf{l}}$. So we can say, Academic learning qualities are not gratifying to persuade students' satisfaction. 
$\mathrm{H}_{3}$ : Organisational and student development facilities are commendable to secure students' satisfaction.

From the table 4 for organizational and student development facilities the significance (pvalue) is 0.585 ; this value is higher than to $\boldsymbol{\alpha}$ level 0.05 for this test. An equal variances $t$-test failed to reveal a statistically reliable difference between the mean number of female $(\mathrm{M}=3.11, \mathrm{SD}=$ $.64)$ and male $(\mathrm{M}=2.97, \mathrm{SD}=.60), t(85)=-.950, p=.345, \alpha=.05$. If $\mathbf{p} \leq \boldsymbol{\alpha}$, then reject $\mathrm{H}_{0}$. In organizational and student development facilities, $\mathrm{p}=(0.345)$ is greater than 0.05 , so we accepted $\mathbf{H}_{0}$ and reject $\boldsymbol{H}_{1}$. So we can say, organizational and student development facilities are not commendable to secure students' satisfaction.

\section{H4: Assessment methods and student feedbacks are favourable to promote students' satisfaction.}

From the table 4 for assessment methods and student feedbacks the significance (p-value) is 0.844 ; this value is higher than to $\boldsymbol{\alpha}$ level 0.05 for this test. An equal variances $t$-test failed to reveal a statistically reliable difference between the mean number of female $(\mathrm{M}=3.41, \mathrm{SD}=.61)$ and male $(\mathrm{M}=3.30, \mathrm{SD}=.59), t(85)=-0.835, p=.406, \alpha=.05$. If $\mathbf{p} \leq \boldsymbol{\alpha}$, then reject $\mathbf{H}_{0}$. In Assessment Methods \& student feedback, $\mathrm{p}=(0.406)$ is greater than 0.05 , so we accepted $\mathbf{H}_{0}$ and reject $\boldsymbol{H}_{1}$. So we can say Assessment methods and student feedbacks are not favorable to promote students' satisfaction.

\section{RESULT AND DISCUSSION \\ Demographic characteristics of the respondents}

Table 5. Demographic characteristics of the respondents

\begin{tabular}{|l|l|c|c|}
\hline \multirow{2}{*}{ Gender } & Characteristics & Frequency & Percent (\%) \\
& Male & 63 & 72.4 \\
\cline { 2 - 4 } & Female & 24 & 27.6 \\
\hline \multirow{4}{*}{ Age } & Below 20 & 11 & 12.6 \\
\cline { 2 - 4 } & $20-$ below 30 & 76 & 87.4 \\
\hline \multirow{3}{*}{$\begin{array}{l}\text { Pame of } \\
\text { Obtained }\end{array}$} & BBA/Hons & 22 & 25.3 \\
\cline { 2 - 4 } degree & MBA/EMBA/MSc & 26 & 29.9 \\
\cline { 2 - 4 } & Others & 39 & 44.8 \\
\hline \multirow{3}{*}{$\begin{array}{l}\text { No. of years } \\
\text { studying }\end{array}$} & HSC & 51 & 58.6 \\
\cline { 2 - 4 } & Diploma & 2 & 2.3 \\
\cline { 2 - 4 } & Graduate & 34 & 39.1 \\
\cline { 2 - 4 } & Less than 1 year & 6 & 6.4 \\
\cline { 2 - 4 } & 3 to 2 years & 38 & 43.7 \\
\cline { 2 - 4 } & 5 to 6 years & 36 & 41.4 \\
\cline { 2 - 4 } & More than 6 years & 4 & 4.6 \\
\hline
\end{tabular}

Table 5 shows the demographic profile of the participants. It shows that approximately two-thirds of the respondents $(72.4 \%)$ are male, and $27.6 \%$ are female. We categorised the age group into two groups, where $12.6 \%$ are from less than 20 years of age, and $87.4 \%$ are from 20 to 
below 30. The program they involve in the current university is categorised into three groups. $25.3 \%$ are from B.B.A./Hon's, where $29.9 \%$ are from MBA/EMBA/MSc, and $44.8 \%$ are from the grouping of the other. The latest degree obtained from the HSC category is $58.6 \%$, and from the diploma and graduate category are $2.3 \%$ and $39.1 \%$, respectably. The number of years studying in this current university is categorised as less than one year, 1 to 2 years, 3 to 4 years, 5 to 6 years, More than six years where the percentage is $3.4 \%, 6.9 \%, 43.7 \%, 41.4 \%$, and $4.6 \%$ respectably.

\section{Correlation Analysis}

Table 6. Correlation Matrix of Dependent Variable and Independent Variables

\begin{tabular}{|c|c|c|c|c|c|c|}
\hline & & 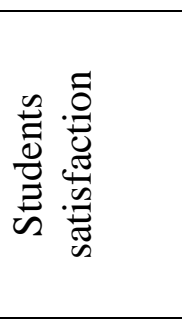 & 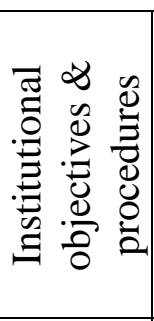 & 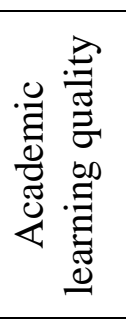 & 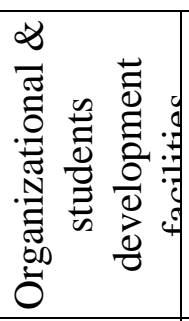 & 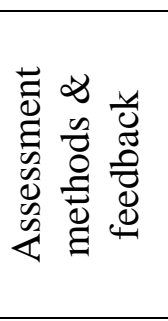 \\
\hline \multirow{5}{*}{$\begin{array}{c}\text { Pearson } \\
\text { Correlation }\end{array}$} & Students satisfaction & 1.000 & .239 & .306 & .232 & .499 \\
\hline & $\begin{array}{l}\text { Institutional objectives \& } \\
\text { procedures }\end{array}$ & .239 & 1.000 & .597 & .563 & .409 \\
\hline & Academic learning quality & .306 & .597 & 1.000 & .568 & .430 \\
\hline & $\begin{array}{l}\text { Organizational \& students } \\
\text { development facilities }\end{array}$ & .232 & .563 & .568 & 1.000 & .475 \\
\hline & Assessment methods \& feedback & .499 & .409 & .430 & .475 & 1.000 \\
\hline \multirow{5}{*}{$\begin{array}{l}\text { Sig. }(1- \\
\text { tailed) }\end{array}$} & Students satisfaction & . & .013 & .002 & .015 & .000 \\
\hline & $\begin{array}{l}\text { Institutional objectives \& } \\
\text { procedures }\end{array}$ & .013 & & .000 & .000 & .000 \\
\hline & Academic learning quality & .002 & .000 & . & .000 & .000 \\
\hline & $\begin{array}{l}\text { Organizational \& students } \\
\text { development facilities }\end{array}$ & .015 & .000 & .000 & & .000 \\
\hline & Assessment methods \& feedback & .000 & .000 & .000 & .000 & \\
\hline \multirow{5}{*}{$\mathrm{N}$} & Students satisfaction & 87 & 87 & 87 & 87 & 87 \\
\hline & $\begin{array}{l}\text { Institutional objectives \& } \\
\text { procedures }\end{array}$ & 87 & 87 & 87 & 87 & 87 \\
\hline & Academic learning quality & 87 & 87 & 87 & 87 & 87 \\
\hline & $\begin{array}{l}\text { Organizational \& students } \\
\text { development facilities }\end{array}$ & 87 & 87 & 87 & 87 & 87 \\
\hline & Assessment methods \& feedback & 87 & 87 & 87 & 87 & 87 \\
\hline
\end{tabular}

The association between the control variable and the independent variables can be seen in table 6. The analysis showed a poor positive linear association between institutional goals \& procedures and students' satisfaction, where the Pearson coefficient of correlation is $(0.239)$. On the other hand, a positive correlation coefficient (0.306) occurs between the efficiency of institutional student instruction and the happiness of learners. It means that there's a good 
connection over a week. Similarly, the correlation coefficient between facilities for organisational \& student development and students' satisfaction (0.232) demonstrates a positive and weak linear relationship between facilities for organisational \& student development and students' satisfaction. The correlation coefficient between evaluation methods \& feedback and the satisfaction of students (0.500) indicates that a positive and intermediate linear relationship occurs between evaluation methods \& feedback and the satisfaction of students. The p-value is less than 0.05 in both aspects, so we should dismiss the null hypothesis at a 5 per cent significance level and infer an essential correlation between student satisfaction and other independent variables.

\section{Multiple Regression Analysis}

This study also escorted multiple regression analysis to determine the impact of independent variables institutional objectives \& procedures, academic learning quality, organisational \& student's development facilities, assessment methods \& feedback on student satisfaction. The contemplated model is presented below.

$$
\mathrm{Y}=\alpha+\beta_{1} * \mathrm{OP}+\beta_{2} * \mathrm{LQ}+\beta_{3} * \mathrm{SD}+\beta_{4} * \mathrm{AF}+\varepsilon
$$

Where, $\mathrm{Y}=$ Dependent variable (Student satisfaction) $\mathrm{OP}=$ Independent variable (Institutional objectives \& procedures)

$\mathrm{LQ}=$ Independent variable (Academic learning quality)

$\mathrm{SD}=$ Independent variable (Students development facilities)

$\mathrm{AF}=$ Independent variable (Assessment methods \& feedback)

$\alpha=$ Constant term

$\beta_{1}, \beta_{2}, \beta_{3}, \beta_{4}=$ Coefficient of independent variables

$\varepsilon=$ the error/disturbance term

Table 7. Summary of Analysis of Variance (ANOVA ${ }^{a}$ )

\begin{tabular}{|l|l|r|r|r|r|c|}
\hline \multicolumn{7}{|l|}{ ANOVA $^{\text {a }}$} \\
\hline Model & Sum of Squares & df & Mean Square & F & Sig. \\
\hline \multirow{3}{*}{1} & Regression & 33.484 & 4 & 8.371 & 7.284 & $.000^{\mathrm{b}}$ \\
\cline { 2 - 7 } & Residual & 94.240 & 82 & 1.149 & \\
\cline { 2 - 6 } & Total & 127.724 & 86 & & & \\
\hline
\end{tabular}

Table 7 provides a description of the effects of the variance analysis (ANOVA). The value of Statistics F (ANOVA) can be shown to be 7.284 with a degree of significance (ANOVA Sig.) of 0.000 (i.e., Sig. $=0.000<0.05$ ). It shows that for this research, the linear regression model is statistically substantially relevant. Figure- 9 shows a description of the multiple regression analysis results. The research showed that the value of $\mathrm{R}$ is $0.512>0.50$. This suggests that this model is ideal for determining the relationship between dependent and independent variables. Moreover, the value of $\mathrm{R}^{2}$ of 0.262 indicates that $26.2 \%$ of students' satisfaction is explained by the multiple linear regression models. In addition, the Durbin- Watson test statistics is 1.523 (i.e. $\mathrm{d}=1.523$ ). 
The range is $(1.5<\mathrm{d}<2.5)$. It indicates that there is no auto-correlation in our multiple regression data.

Table 8. The Results of Regression Analysis

\begin{tabular}{|c|c|c|c|c|c|c|}
\hline \multicolumn{7}{|c|}{ Coefficients $^{\mathbf{a}}$} \\
\hline \multirow{2}{*}{\multicolumn{2}{|c|}{ Model }} & \multicolumn{2}{|c|}{$\begin{array}{l}\text { Unstandardised } \\
\text { Coefficients }\end{array}$} & \multirow{2}{*}{$\begin{array}{c}\text { Standardised } \\
\text { Coefficients } \\
\text { Beta }\end{array}$} & \multirow[t]{2}{*}{$\mathrm{t}$} & \multirow[t]{2}{*}{ Sig. } \\
\hline & & $\mathrm{B}$ & Std. Error & & & \\
\hline \multirow[t]{5}{*}{1} & (Constant) & -.399 & .870 & & -.458 & .648 \\
\hline & $\begin{array}{l}\text { Institutional objectives \& } \\
\text { procedures }\end{array}$ & .006 & .289 & .003 & .021 & .983 \\
\hline & Academic learning quality & .355 & .316 & .144 & 1.126 & .264 \\
\hline & Students development facilities & -.150 & .253 & -.075 & -.592 & .555 \\
\hline & $\begin{array}{l}\text { Assessment methods \& } \\
\text { feedback }\end{array}$ & .970 & .229 & .471 & 4.234 & .000 \\
\hline
\end{tabular}

a. Dependent Variable: Student satisfaction

b. Predictors: (Constant), Institutional objectives \& procedures, Academic learning quality, Organizational \& students development facilities, Assessment methods \& feedback

Finally, based on the findings of coefficients shown in Table 8, the multiple linear regression equation is as below:

$$
\mathrm{Y}=-0.399+0.003 * \mathrm{OP}+0.144 * \mathrm{LQ}-0.075 * \mathrm{SD}+0.471 * \mathrm{AF}
$$

From the standardised beta column, we can see assessment methods \& feedback (beta 0.471) are the most influential among the independent variables. In other words, assessment methods \& feedback have the strongest impact on student satisfaction. Academic learning quality with beta 0.144 has the second most influential factor in student satisfaction. Institutional objectives \& procedures contain the beta value of 0.003 , which means it positively impacts student satisfaction. The students' development facilities with beta -0.075 have a negative impact on student satisfaction.

\section{CONCLUSIONS AND RECOMMENDATION}

The study is conducted to explore the level of student satisfaction in major public universities in Bangladesh. We all know that our government allots a cosmic amount of funds in our public universities. Our incumbent government is emboldened for quality education in every stratum of our higher education sector. But in the true sense, public university students are not come by worldclass facilities in terms of research, academic and co-curricular activities. We focused on revealing the actual picture in our public university to inferences the students' facilities provided there. We distributed a questionnaire to major public university students to know the real scenario of student's satisfaction. We used statistical measures to find out the results. Four major public university students were selected as respondents. Among the respondents, male respondents were $72.4 \%$ of the total population, whereas female respondents were $27.4 \%$ of the total population. The majority 
of the student population was between 18 to 26 years of age group. The study results suggest that the facilities students get from the university Institutional objectives \& procedures, academic learning quality, organisational \& student development facilities, assessment methods \& feedback have a significant effect on student satisfaction. The study recommends that universities take adequate steps to satisfy students, such as corroborate politics-free campus facilities, academic objectives and procedures are to be maintained, organisational \& students development facilities must be ensured, academic learning quality needs to be satisfactory, and the assessment must be assessed procedure should be stupendous. The concerning authorities of our public universities should make proper efforts to ensure quality education to our students and motivating students for research activities. The study's findings will help government authorities and higher educational institutions authorities implement the recommendation to satisfy the students of our public university.

\section{REFERENCES}

Ahmed, I., Bhuiyan, M. E. M., Helal, M. S. A., \& Banik, N. (2020). Hybrid Instruction: Post COVID-19 Solution for Higher Education in Bangladesh. International Journal for Modern Trends in Science and Technology, 6(10), 20-25.

Clewes, D. (2011). A student-centred conceptual model of service quality in higher education. Quality in Higher Education, 9(1), 69-85.

Chaudhary, A.R., Iqbal A., \& Gillani, S.Y.M. (2009). The nexus between higher education and economic growth: An empirical investigation for Pakistan. Pakistan Journal of Commerce and Social Sciences. 3, 01-09.

Douglas, J. (2011). Evaluating teaching quality. Quality in Higher Education, 12(1), 3-12.

Gruber, T., Fub, S., Voss, R., \& Gläser-Zikuda, M. (2010). Examining Student Satisfaction with Higher Education Services Using a New Measurement Tool. International Journal of Public Sector Management, 23(2), 105-123.

Harvey, L., \& Green, D. (2012). Defining quality, Assessment \& Evaluation in Higher Education. The New Review of Academic Librarianship, 18(1), 9-34.

Henning, T., Langer, M., \& Hansen, U. (2001). Modelling and managing student loyalty review of the literature on higher education marketing. International Journal of Public Sector Management, 19(2), 316-38.

Helal, M. S. A., Ahmed, I., \& Bhuiyan, M. E. M. (2021). Impact of Education Management Information System (EMIS) on Teaching-Learning Development. International Journal of Academic Research in Progressive Education and Development, 10(2), 948-956. https://doi.org/10.6007/IJARPED/v10-i2/10443

Islam, K. M., \& Salma, U. (2016). The Role of Private Universities in Higher Education of Bangladesh: An Empirical Investigation. International Journal of Finance and Banking Research, 2(4), 121-128. 
Marilyn, R. (2005). Marketing education: a review of service quality perceptions among international students. International Journal of Contemporary Hospitality Management, $17(1), 65-77$.

Mobasser, M., \& Muhammed, B.H. (2010). Higher education in Bangladesh: Status, issues, and prospects. Pakistan Journal of Social Sciences (PJSS), 30(2), 293-305.

Nadiri, H., Kandampully, J., \& Hussain, K. (2009). Students' perceptions of service quality in higher education, Total Quality Management, 20(5), 523-535.

Rodney, A., \& John, H. (2009). An empirical model of international student satisfaction. Asia Pacific Journal of Marketing and Logistics, 21(4), 555-569.

Zeithaml, V. A., Bitner, M. J., \& Gremler, D. D. (2010). Services marketing strategy, Wiley International Encyclopedia of Marketing.

\section{Copyrights}

Copyright for this article is retained by the author(s), with first publication rights granted to the journal. This is an open-access article distributed under the terms and conditions of the Creative Commons Attribution license (https://creativecommons.org/licenses/by/4.0) 